\title{
Case Report: Feasibility and Safety of Autologous NK Cell Therapy in Patients with Cancer
}

\author{
Supansa Nilubol ${ }^{1,2}$, Worawit Kitisakronnakorn ${ }^{3}$, Pimjai Naigovit ${ }^{1,2}$ \\ ${ }^{1}$ LBM Stem Cell Research Unit, Life Balance Methodology Co., Ltd., Bangkok, Thailand \\ ${ }^{2}$ National Institute of Health, Ministry of Public Health, Nonthaburi, Thailand \\ ${ }^{3}$ Better Being Hospital, Bangkok, Thailand \\ Email: Info@lbmet.com
}

How to cite this paper: Nilubol, S., Kitisakronnakorn, W. and Naigovit, P. (2021) Case Report: Feasibility and Safety of Autologous NK Cell Therapy in Patients with Cancer. Journal of Cancer Therapy, 12, 725-735.

https://doi.org/10.4236/jct.2021.1212063

Received: July 29, 2021

Accepted: December 24, 2021

Published: December 27, 2021

Copyright $\odot 2021$ by author(s) and Scientific Research Publishing Inc. This work is licensed under the Creative Commons Attribution International License (CC BY 4.0).

http://creativecommons.org/licenses/by/4.0/

\begin{abstract}
This study reported two cases of Thai cancer patients, including a 36-year-old female with thyroid cancer of more than 5 years and a 64-year-old male with lung and colon cancers of more than 10 years. The written informed consent was provided for autologous natural killer (NK) cell infusion at the anti-ageing and regenerative medicines clinic. Briefly, the blood was taken from the patient for NK cell count and their cytotoxic activity. Then, the patient's NK cells were expanded in vitro, characterized and then counted before being delivered to the same patient by a single intravenous infusion. The vital signs and general physical examinations were observed for $2-6$ hours after the infusion. The patients were discharged if there were no adverse effects. The data showed the increasing number of NK cells and level of cytotoxic activity after the NK cell treatment, compared to the pre-treatment. In addition, the increasing total live cell concentration, as identified by the high percentage of CD56 $6^{\text {dim}} / \mathrm{CD} 16^{\text {bright }}$ cytotoxic NK cells, at day 21 of the NK cell expansion was consistent with the increasing cytotoxic activity of the patients after the treatment. Here, we demonstrated that this autologous NK cell therapy might be feasible; however, the study did not aim to evaluate the anti-cancer effect.
\end{abstract}

\section{Keywords}

Natural Killer Cells, NK Cell Therapy, Cancer, Mono-Treatment, Rejuvenation

\section{Introduction}

Natural Killer (NK) cells are accounted for 5\% - 15\% of lymphocytes in the peripheral blood. Besides, they reside in lymphoid and non-lymphoid organs such 
as the spleen, lungs, and liver. The NK cells are characterized by the expression of $\mathrm{CD} 56^{\text {bright }} \mathrm{CD} 16^{\mathrm{dim} /-}$ (accounting for less than $15 \%$ of total NK cells in the blood which are less mature and less potent cytokine-producing capacity) and the expression of $\mathrm{CD} 56^{\mathrm{dim}} \mathrm{CD} 16^{+}$(accounting for most NK cells which are more mature and more potent cytotoxicity) [1] [2] [3]. Although the NK cells are lymphocytes, they can function as an innate immune system that requires no prior sensitization [4] [5] [6].

Potential effects of NK cells against cancer have been demonstrated on several occasions, including hematopoietic stem cell transplantation (HSCTs), bone marrow transplantation and isolated NK cell infusion. In a previous report, the infusion of NK cells of HLA-haploidentical donors in a patient with aggressive acute myeloid leukemia (AML) could prohibit the disease relapse and metastasis [7] [8] [9]. In addition to hematological malignancies, the effects of NK cells against solid cancers, including metastatic colorectal cancer, glioblastoma, and ovarian cancer, have been demonstrated either in preclinical xenograft models or early clinical studies [10] [11] [12] [13]. Moreover, the safety of the NK cell-based therapy was demonstrated in both allogeneic haploidentical and autologous settings [9] [14] [15] [16].

In allogenic NK cell-based therapy, the contaminated T cells are of concern as they can trigger the potential adverse effects from Graft Versus Host Diseases (GVHD). On the contrary, the GVHD is less likely in autologous NK cell transfusion [17]. Recently, the methods for NK activation, expansion, and purification have been dramatically improved. Therefore, the NK cells could be purified before the cell expansion to minimize cell contamination. In addition, the cell expansion technique allowed the cell number to achieve the therapeutic level [17].

From research to clinical use, human NK cell activation and expansion kits are now available. Of note, FDA-approved Interleukin-2 (IL-2), the key cytokine for NK cell survival and cytotoxicity activation has been used for several cancer treatments [18] [19]. However, the efficiency of NK cell culture, in terms of survival period and yields of cells, highly depends on the quality and characteristics of the kits and the cell sources. For example, $1.59 \times 10^{10}$ NK cells with $92.37 \%$ purity can be yielded from umbilical cord blood-derived NK progenitor expansion at 21 days [20]. In comparison, 21-day NK cultures from the placenta yielded only $1.2 \times 10^{9} \mathrm{NK}$ cells with $80 \%$ viability [21]. However, the recommended maximum tolerated dose, total dosage amount, and dosage intervals remained inconclusive [9] [15] [16] [22] [23] [24].

From several clinical studies, the feasibility of utilizing NK cells for cancer immunotherapy in both hematological and solid cancers has gained increasing evidence. Moreover, the clinical scale ex vivo NK cell activation and expansion kit are now commercially available. The NK cell-based therapy thus became an alternative therapeutic tool or an adjuvant to the standard cancer treatment such as surgery, radiation and chemotherapy. This study demonstrated an increasing 
NK cell number with improving cytotoxic activity in two Thai patients with cancers after the infusion of autologous NK cell therapy. The data also showed the increasing concentration of total live cells at day 21 of NK cell expansion with a high percentage of $\mathrm{CD} 56^{\mathrm{dim}} / \mathrm{CD} 16^{\text {bright }}$ cytotoxic NK cells, consistent with the increasing cytotoxic activity in the patient after treatment. We, therefore, suggested that this autologous NK cell therapy might be feasible. However, our study did not design to explore the anti-cancer effect.

\section{Case Report}

A 36-year-old Thai female patient with thyroid cancer of more than 5 years and a 64-year-old Thai male patient with lung and colon cancers of more than 10 years were included in the study. The patients provided written informed consent to receive the autologous natural killer cell infusion for cancer therapy. All processes of the NK cell therapy were performed under the physician supervision. Prior to the treatment, the patients were screened for infections of the human immunodeficiency virus (HIV), hepatitis B virus (HBV), and hepatitis C virus (HCV), systemic inflammation and liver function test. Moreover, complete blood count $(\mathrm{CBC})$, natural killer cell (NK Cell) count, and NK cell activity were evaluated. A $3.0 \mathrm{ml}$ EDTA blood (VACUETTE, Thailand) was collected for evaluating the complete blood count (CBC) and NK cell count. The cluster of differentiation (CD) marker expression as $\mathrm{CD} 56^{+} / 16^{+} / 3^{-}$was used for NK cell characterization by the flow cytometer. A $10-12 \mathrm{ml}$ lithium heparinized blood (VACUETTE, Thailand) was collected to evaluate the NK cell activity. In the NK activity assay, the NK cells from patient blood were used as the effector cells (E) while human tumor $\mathrm{K} 562$ cell lines (ATCC ${ }^{\circledR} \mathrm{CCL}_{243^{\mathrm{TM}}}$, USA) were used as the target cells (T). NK effector cells were incubated with K562 target cells at different E:T ratios (ranged from 50:1 to $12.5: 1$ ) in a $37^{\circ} \mathrm{C}$ humidified incubator with $5 \% \mathrm{CO}_{2}$ for 4 hours. The NK cell activity was measured by a microfluorometer for the female patient and a flow cytometry-based NK cytotoxicity assay for the Thai male patient.

After the patient enrolment, the $50.0-100.0 \mathrm{ml}$ heparinized blood samples were collected and then immediately processed to ensure the highest efficiency of isolated peripheral blood mononuclear cells (PBMCs). Briefly, the blood samples were centrifuged at $2000 \mathrm{rpm}$ at $22^{\circ} \mathrm{C}$ for $10 \mathrm{~min}$ to separate the top auto-plasma layer. Next, the bottom layer of the concentrated blood sample was diluted with RPMI 1640 medium (Corning ${ }^{\circledR}$, USA). The diluted samples were carefully layered on the lymphocyte separation medium (Corning ${ }^{\circledR}$, USA) and then centrifuged at $2000 \mathrm{rpm}$ at $22^{\circ} \mathrm{C}$ for $20 \mathrm{~min}$. The PBMCs layer was collected and measured the cell number by dual-fluorescence dye using Luna automated cell counter (Logos Biosystems ${ }^{\circledR}$, Korea). The density of PBMCs samples was adjusted to $1 \times 10^{6}$ cells/ml with KBM NK primary medium (Corning ${ }^{\circledR}$, China) supplemented by $1.8 \mathrm{ml}$ of KBM NK primary supplement and $10 \%$ of auto-plasma. The PBMCs were transferred into an antibody pre-coated $75 \mathrm{~cm}^{2}$ cell 
culture flask (Corning ${ }^{\circledR}$, China) and humidified incubated at $37^{\circ} \mathrm{C}$ under $5 \%$ $\mathrm{CO}_{2}$. After 5 - 6 days of NK cells activation (cell density was more than $2 \times 10^{6}$ cells $/ \mathrm{ml}$ ), non-adherent NK cells were mixed with an appropriate volume of KBM NK Expansion medium (Corning ${ }^{\circledR}$, China) containing $1000 \mathrm{IU} / \mathrm{ml}$ of IL-2 (StemCell Technologies ${ }^{\circledR}$, United States) and $10 \%$ of auto-plasma. The cell mixture was then transferred into a gas-permeable culture bag (Corning ${ }^{\circledR}$, China) and humidified incubated at $37^{\circ} \mathrm{C}$ under $5 \% \mathrm{CO}_{2}$ for 21 days. NK cell samples were collected to measure NK cells number every 2 - 3 days by dual-fluorescence dye using Luna automated cell counter (Logos Biosystems ${ }^{\circledR}$, Korea) for cell viability record. The high capacity of proliferation was observed in the female patient, as the NK cell number was increased to $6660.0 \times 10^{6}$ cells with $99.9 \%$ viability at 21 days, compared with $14.9 \times 10^{6}$ cells at day 3 of incubation (Figure 1 (a)). In the male patient, the NK cell number increased from $19.0 \times 10^{6}$ cells to $8280.0 \times 10^{6}$ cells with $99.6 \%$ viability (Figure $1(\mathrm{~b})$ ).

In addition, at day 20 of cell expansion, the NK cells were subjected for quality control tests including immunophenotyping $\left(\mathrm{CD}^{5} 6^{+} / 3^{-}\right.$for the $\mathrm{NK}$ cell marker, CD56 $6^{\mathrm{dim}} / \mathrm{CD} 16^{\text {bright }}$ for the cytotoxic NK cell, CD56 ${ }^{\text {bright }} / \mathrm{CD} 16^{+/-}$for the cytokine-producing $\mathrm{NK}$ cell, and $\mathrm{CD}^{+} / 8^{+}$for the cytotoxic $\mathrm{T}$ cell), and sterility tests (including mycoplasma, endotoxin, bacteria, and fungi) before the batch release. The positive markers in the expanded NK cells included CD56 $/ 3^{-}(61.9 \%)$, CD56 ${ }^{\text {dim }} / \mathrm{CD} 16^{\text {bright }}(43.3 \%), \mathrm{CD} 56^{\text {bright }} / \mathrm{CD} 16^{+/-}(2.4 \%)$ and $\mathrm{CD}^{+} / 8^{+}(19.0 \%)$ (Figure 1(c)) for Thai female patient and $\mathrm{CD} 56^{+} / 3$ (73.6\%), CD56 $\mathrm{dim} / \mathrm{CD} 16^{\text {bright }}$

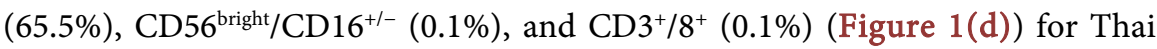
male patient.

The allergy skin test was performed 30 minutes prior to the treatment. After the premedication with intravenous $10 \mathrm{mg}$ chlorphenamine and $10 \mathrm{mg}$ dexamethasone, all 21-day-cultured autologous NK cells were intravenously infused into the patient. The vital signs and general physical examination were monitored for 2 - 6 hours following the infusion, and the patients were discharged if there were no adverse effects.

Three months after autologous NK infusion, patients were evaluated for CBC, NK cell count, and NK activity. The trend of both NK cell count and NK activity was increasing in both patients. NK cell count $\left(\mathrm{CD}^{2} 6^{+} / 16^{+} / 3^{-}\right)$increased in number from $122 \mathrm{cell} / \mathrm{mm}^{3}$ to $486 \mathrm{cell} / \mathrm{mm}^{3}$ in the female patient (Figure 2(a)) and from $598 \mathrm{cell} / \mathrm{mm}^{3}$ to $803 \mathrm{cell} / \mathrm{mm}^{3}$ in the male patient (Figure 2(b)). Consistently, NK activity also increased from $41 \%$ to $49 \%$ in the female patient (Figure 2(c)), which were from $10.30 \%$ to $67.10 \%, 10.80 \%$ to $59.50 \%$, and $11.30 \%$ to $63.30 \%$ at the ratio of $50: 1,25: 1$, and $12.5: 1$, respectively in the male patient (Figure 2(d)).

\section{Discussion}

We demonstrated the feasibility and safety of autologous NK cell therapy in thyroid, lung and colon cancer patients using a commercial expansion method, 


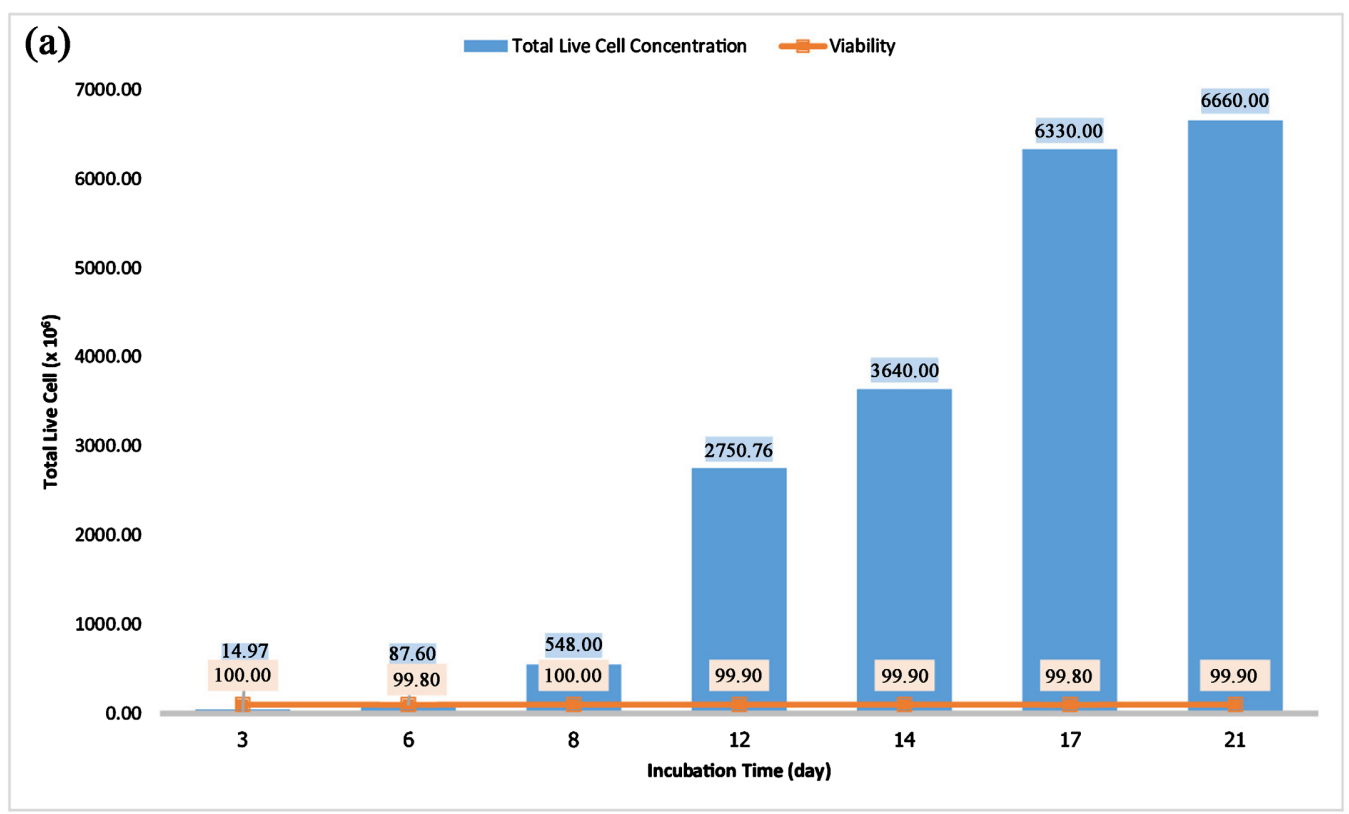

(b) Total Live Cell Concentration $\quad-$ Viability

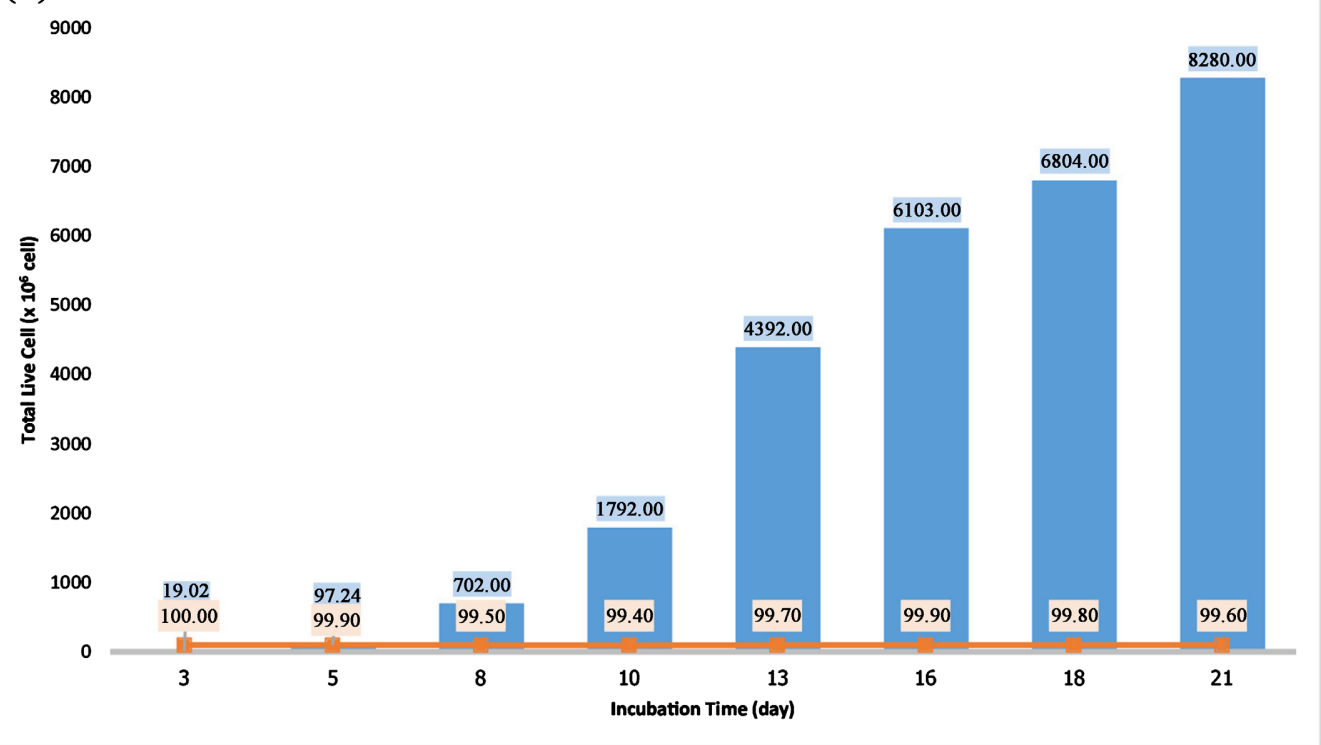

(c) [A AND L AND AA] FL4 Log/FL1 Log-ADC

[A AND L] FL1 Log/FL4 Log-ADC
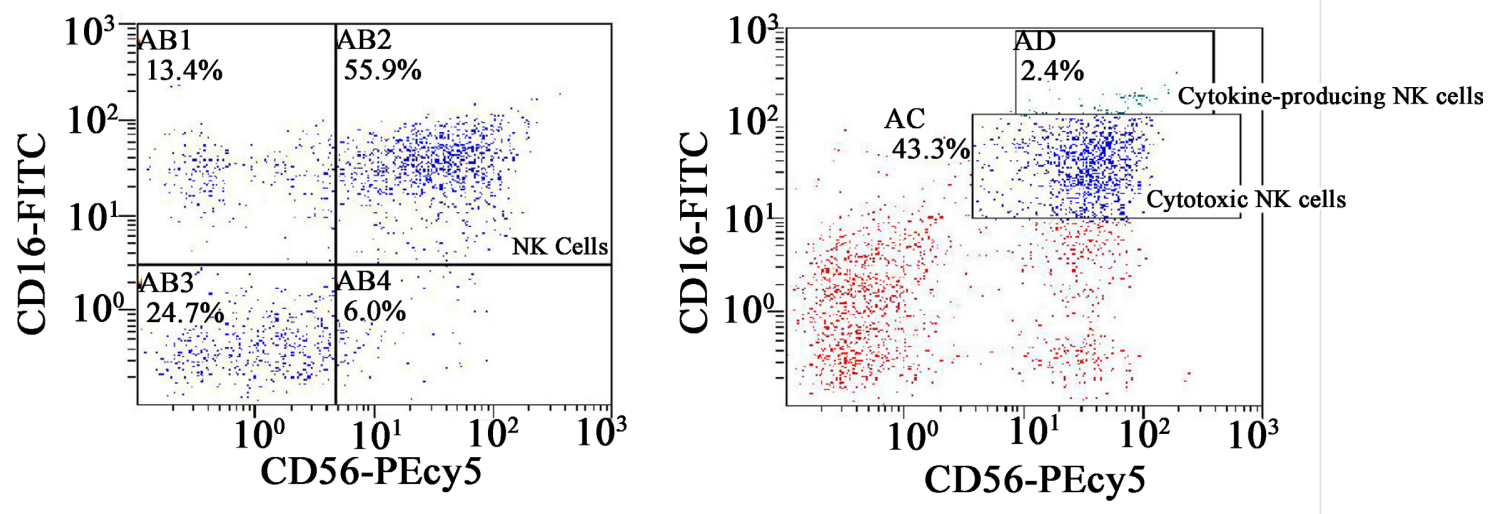
[A AND L AND AB] FL4 Log/FL1 Log-ADC [A AND L AND L AND AA] FL4 Log/FL1 Log-ADC
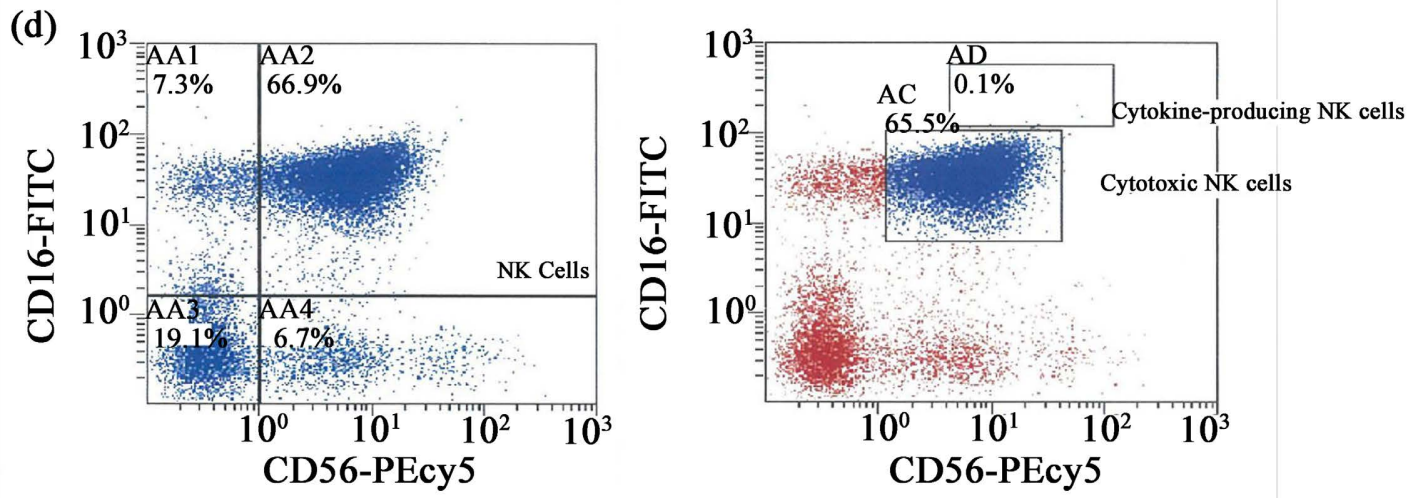

Figure 1. Cell viability and concentration during 21 days of cultivation show high percentage of viability and high capacity of proliferation in both patients. (a) Increasing number of cells up to $6660.0 \times 10^{6}$ cells with 99.9\% viability at 21 days in Thai female patient. (b) Cell number increased from $19.0 \times 10^{6}$ cells to $8280.0 \times$ $10^{6}$ cells with $99.6 \%$ viability in Thai male patient. (c) Immunophenotype of NK cell population in Thai female patient and Thai male patient (d).

(a)

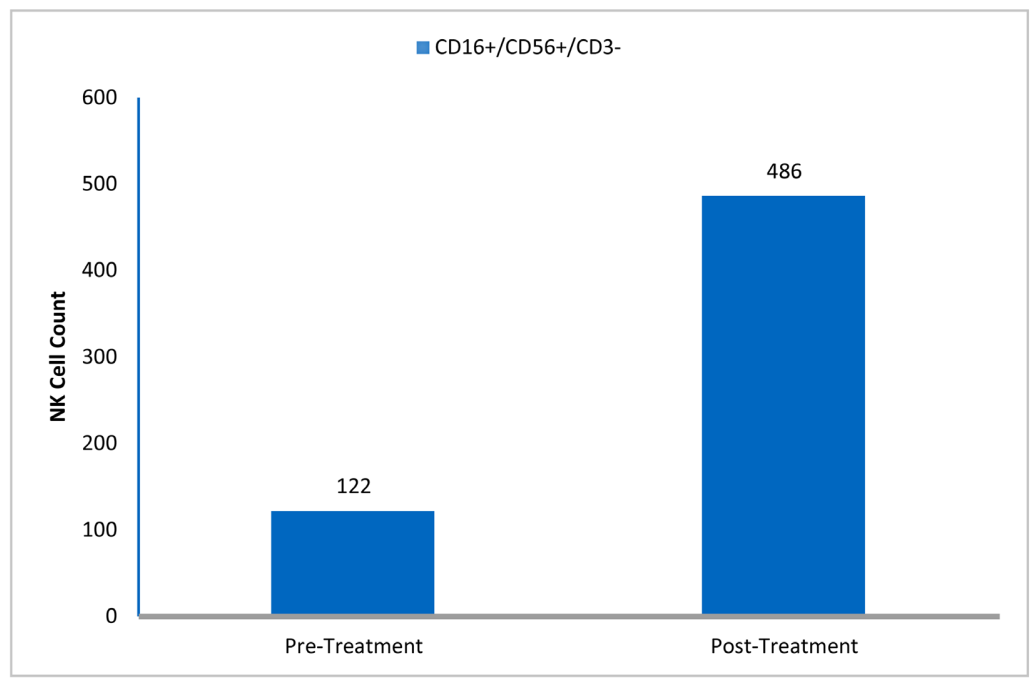

(b)

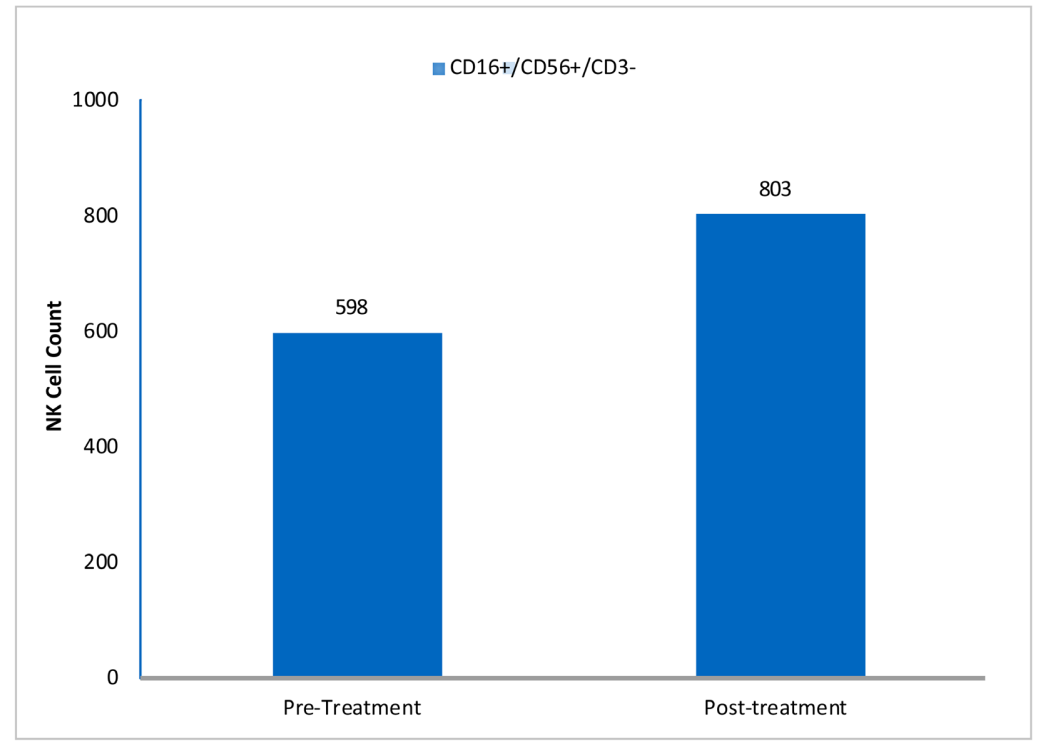


(c)

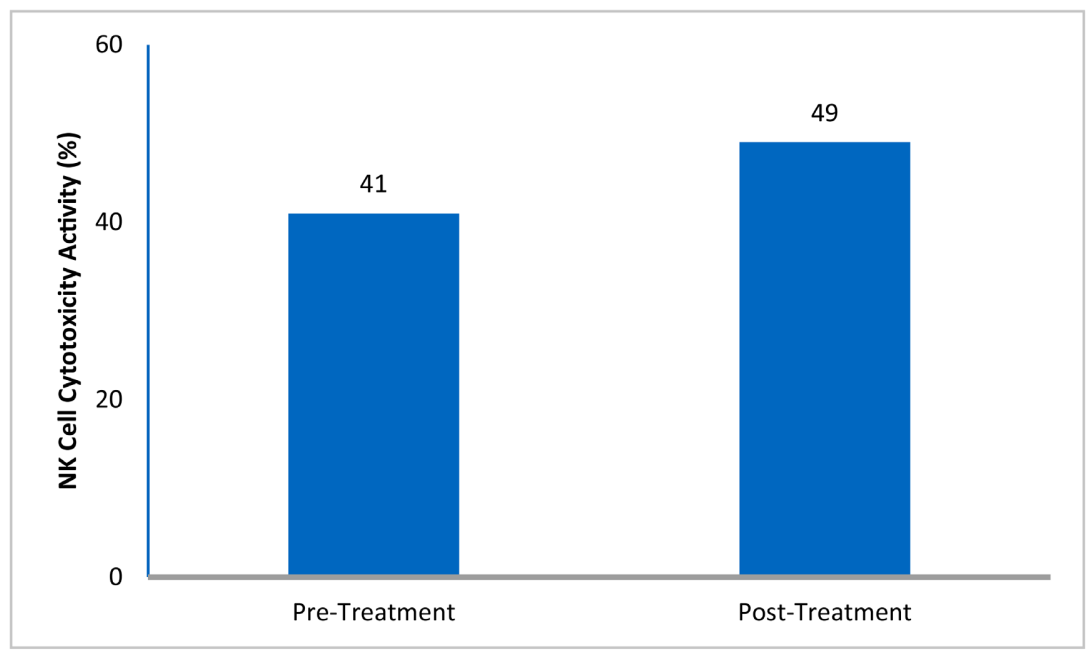

(d)

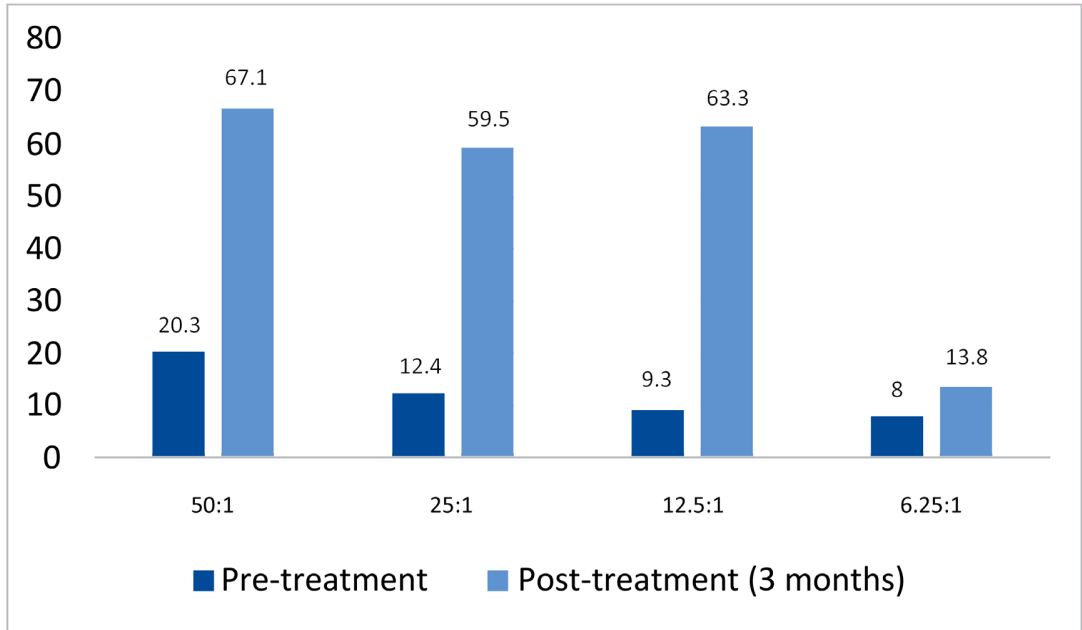

Figure 2. After three months of autologous NK infusion, NK cell count was increased in both female (a) and male (b) patients. Consistently, NK activity also increased in the female patient (c) using micro-fluorometer, and in the male patient (d) using flow cytometry-based NK cytotoxicity assay.

Corning ${ }^{\circledR}$ NK Expansion kit. With the kit, the PBMCs show rapid expansion $\left(\sim 100\right.$-fold proliferation) with high yield $\left(\sim 3 \times 10^{9}\right.$ cells on day 14 from a $30 \mathrm{ml}$ blood sample) and a high level of surface marker expression $\left(83 \%\right.$ of $\mathrm{CD} 56^{+} \mathrm{CD} 3^{-}$ on day 14). In addition, our report demonstrated the purity of the infused NK cells at the therapeutic level for cancer patients. After 21 days of NK cell expansion, total live NK cells were increased, and a high percentage of CD56 $6^{\mathrm{dim}} / \mathrm{CD} 16^{\text {bright }}$ cytotoxic NK cells were observed. These immunophenotypes may be responsible for the increased NK cell cytotoxic activity of the patients after the NK cell infusion for 3 months. Micro-fluorometry and flow cytometry were used for evaluating NK cell cytotoxic activity in different patients. The NK cell activities were compared between pre-and post-treatment in the same patient. Though our report contains the data from only two patients, the quantitative measurement of the NK cell activities could imply the possible therapeutic effects of the NK cell therapy in other cancer patients. Moreover, our study outlined 
the feasibility of NK cell therapy but did not aim to evaluate the anti-cancer effects.

NK cells in peripheral blood are generally found in a small proportion of the lymphocytes. In cancer patients, the NK cells are usually lower in number and have less cytotoxic activity. Therefore, an ex vivo NK cell expansion to reach sufficient cell numbers with improving killing efficiency could benefit cancer patients. Several studies aimed to generate a highly efficient protocol to expand the NK cells with high purity. However, the biggest obstacle is the limited number of pure NK cells without prior NK cell purification. In one study, the use of interleukin-2 (IL-2) can induce an NK cell expansion for up to 50 folds after 2 weeks. Another study revealed 1600-fold NK expansions after 20 days of the cultured NK cells using IL-2 and anti-CD3 induction from the blood of cancer patients, but NK cytotoxicity against K562 cells was lesser than $10 \%$ at 1:1 E/T ratio [25] [26] [27] [28] [29]. While Sakamoto et al. demonstrated the higher level of cytotoxicity $38.77 \%$ at $0.75: 1$ and $57.54 \%$ at $1.56: 1 \mathrm{E} / \mathrm{T}$ ratio [14].

In the expansion kit, the cytokine cocktails mainly comprise IL-2, IL-12, and IL15, which can induce various intracellular signaling events, including Jak1, Jak2, Jak3, STAT1, STAT5, and STAT4 transcriptions, resulting in stimulating cell proliferation and enhancing cytotoxicity of the NK cells. In our cases, the NK cells were expanded to approx. 400 folds at day 21, with the high yield of cell numbers at approx. 6.6 and $8.2 \times 10^{9}$ cells and high level of $\mathrm{CD}^{2} 6^{+} \mathrm{CD}^{-}$at $61.9 \%$ and $73.6 \%$. In our cases, the relatively lower NK cell purity ( $83 \%$ of NK cells) may be due to the lower number of transferred cell numbers and the adjuvant chemotherapy and systemic IL-2 administration in other studies [30].

Using the flow cytometry, the expanded NK cells demonstrated a high level of CD16 surface marker, indicating the NK cell subtypes predominately involved in cytotoxicity and ADCC activation. Furthermore, this finding was correlated with the increasing NK cell cytotoxicity level against the K562 cells after the NK cell therapy. However, as the CD16 expression of the NK cells decreased approx. $30 \%$ after being thawed (data from Phase I clinical trial of autologous NK cell therapy), the fresh blood was used for NK expansion. Additionally, the freshly expanded NK cells were transfused to the patients. Thus, the protocol may explain the high level of $\mathrm{CD} 16^{+} \mathrm{NK}$ cells and the increasing cytotoxic activity in our cases.

\section{Conclusion}

In our cases, we mainly focused on possible toxicities of NK cell therapy, including NK cell purity, cell number, and cytotoxicity activity, to evaluate the safety of the expanded NK cells using the commercial kit. The NK cell expansion can achieve a high level of purity and functionality. In addition, the relatively small amount of NK cells used in the infusion to our patients may guarantee safety. However, the efficacy of NK cells in cancer treatment requires further investigations. 


\section{Acknowledgements}

K562 cells were provided from the Medical Life Sciences Institute, Department of Medical Sciences and Ministry of Public Health, Bangkok, Thailand.

\section{Conflicts of Interest}

The authors declare no conflicts of interest regarding the publication of this paper.

\section{References}

[1] Freud, A.G., et al. (2017) The Broad Spectrum of Human Natural Killer Cell Diversity. Immunity, 47, 820-833. https://doi.org/10.1016/j.immuni.2017.10.008

[2] Bjorkstrom, N.K., Ljunggren, H.G. and Michaelsson, J. (2016) Emerging Insights into Natural Killer Cells in Human Peripheral Tissues. Nature Reviews Immunology, 16, 310-320. https://doi.org/10.1038/nri.2016.34

[3] Abel, A.M., et al. (2018) Natural Killer Cells: Development, Maturation, and Clinical Utilization. Frontiers in Immunology, 9, 1869. https://doi.org/10.3389/fimmu.2018.01869

[4] Kiessling, R., Klein, E. and Wigzell, H. (1975) Natural Killer Cells in the Mouse. I. Cytotoxic Cells with Specificity for Mouse Moloney Leukemia Cells. Specificity and Distribution according to Genotype. European Journal of Immunology, 5, 112-117. https://doi.org/10.1002/eji.1830050208

[5] Lanier, L.L., et al. (1986) Natural Killer Cells: Definition of a Cell Type Rather than a Function. The Journal of Immunology, 137, 2735-2739.

[6] Herberman, R.B., Nunn, M.E. and Lavrin, D.H. (1975) Natural Cytotoxic Reactivity of Mouse Lymphoid Cells against Syngeneic Acid Allogeneic Tumors. I. Distribution of Reactivity and Specificity. International Journal of Cancer, 16, 216-229. https://doi.org/10.1002/ijc.2910160204

[7] Ruggeri, L., et al. (1999) Role of Natural Killer Cell Alloreactivity in HLA-Mismatched Hematopoietic Stem Cell Transplantation. Blood, 94, 333-339.

https://doi.org/10.1182/blood.V94.1.333.413a31 $333 \quad 339$

[8] Ruggeri, L., et al. (2002) Effectiveness of Donor Natural Killer Cell Alloreactivity in Mismatched Hematopoietic Transplants. Science, 295, 2097-2100.

https://doi.org/10.1126/science. 1068440

[9] Miller, J.S., et al. (2005) Successful Adoptive Transfer and in Vivo Expansion of Human Haploidentical NK Cells in Patients with Cancer. Blood, 105, 3051-3057. https://doi.org/10.1182/blood-2004-07-2974

[10] Gras Navarro, A., et al. (2014) NK Cells with KIR2DS2 Immunogenotype Have a Functional Activation Advantage to Efficiently Kill Glioblastoma and Prolong Animal Survival. The Journal of Immunology, 193, 6192-6206.

https://doi.org/10.4049/jimmunol.1400859

[11] Veluchamy, J.P., et al. (2017) In Vivo Efficacy of Umbilical Cord Blood Stem Cell-Derived NK Cells in the Treatment of Metastatic Colorectal Cancer. Frontiers in Immunology, 8, 87. https://doi.org/10.3389/fimmu.2017.00087

[12] Geller, M.A., et al. (2013) Intraperitoneal Delivery of Human Natural Killer Cells for Treatment of Ovarian Cancer in a Mouse Xenograft Model. Cytotherapy, 15, 1297-1306. https://doi.org/10.1016/j.jcyt.2013.05.022 
[13] Lee, S.J., et al. (2015) Natural Killer (NK) Cells Inhibit Systemic Metastasis of Glioblastoma Cells and Have Therapeutic Effects against Glioblastomas in the Brain. BMC Cancer, 15, 1011. https://doi.org/10.1186/s12885-015-2034-y

[14] Sakamoto, N., et al. (2015) Phase I Clinical Trial of Autologous NK Cell Therapy Using Novel Expansion Method in Patients with Advanced Digestive Cancer. Journal of Translational Medicine, 13, 277. https://doi.org/10.1186/s12967-015-0632-8

[15] Rubnitz, J.E., et al. (2010) NKAML: A Pilot Study to Determine the Safety and Feasibility of Haploidentical Natural Killer Cell Transplantation in Childhood Acute Myeloid Leukemia. Journal of Clinical Oncology, 28, 955-959. https://doi.org/10.1200/JCO.2009.24.4590

[16] Iliopoulou, E.G., et al. (2010) A Phase I Trial of Adoptive Transfer of Allogeneic Natural Killer Cells in Patients with Advanced Non-Small Cell Lung Cancer. Cancer Immunology, Immunotherapy, 59, 1781-1789. https://doi.org/10.1007/s00262-010-0904-3

[17] Ferrara, J.L., et al. (2009) Graft-versus-Host Disease. The Lancet, 373, 1550-1561. https://doi.org/10.1016/S0140-6736(09)60237-3

[18] Berraondo, P., et al. (2019) Cytokines in Clinical Cancer Immunotherapy. British Journal of Cancer, 120, 6-15. https://doi.org/10.1038/s41416-018-0328-y

[19] Lotze, M.T., et al. (1981) Lysis of Fresh and Cultured Autologous Tumor by Human Lymphocytes Cultured in T-Cell Growth Factor. Cancer Research, 41, 4420-4425.

[20] Mu, Y.X., et al. (2019) A Simple Method for in Vitro Preparation of Natural Killer Cells from Cord Blood. BMC Biotechnology, 19, 80. https://doi.org/10.1186/s12896-019-0564-0

[21] Kang, L., et al. (2013) Characterization and ex Vivo Expansion of Human Placenta-Derived Natural Killer Cells for Cancer Immunotherapy. Frontiers in Immunology, 4, 101. https://doi.org/10.3389/fimmu.2013.00101

[22] Geller, M.A., Cooley, S., Judson, P.L., Ghebre, R., Carson, L.F., Argenta, P.A., Jonson, A.L., Panoskaltsis-Mortari, A., Curtsinger, J., McKenna, D., Dusenbery, K., Bliss, R., et al. (2011) A Phase II Study of Allogeneic Natural Killer Cell Therapy to Treat Patients with Recurrent Ovarian and Breast Cancer. Cytotherapy, 13, 98-107. https://doi.org/10.3109/14653249.2010.515582

[23] Arai, S., Meagher, R., Swearingen, M., Myint, H., Rich, E., Martinson, J. and Klingemann, H. (2008) Infusion of the Allogeneic Cell Line NK-92 in Patients with Advanced Renal Cell Cancer or Melanoma: A Phase I Trial. Cytotherapy, 10, 625-632. https://doi.org/10.1080/14653240802301872

[24] Krause, S.W., Gastpar, R. andreesen, R., Gross, C., Ullrich, H., Thonigs, G., Pfister, K. and Multhoff, G. (2004) Treatment of Colon and Lung Cancer Patients with ex Vivo Heat Shock Protein 70-Peptide-Activated, Autologous Natural Killer Cells: A Clinical Phase I Trial. Clinical Cancer Research, 10, 3699-3707. https://doi.org/10.1158/1078-0432.CCR-03-0683

[25] Sutlu, T. and Alici, E. (2009) Natural Killer Cell-Based Immunotherapy in Cancer: Current Insights and Future Prospects. Journal of Internal Medicine, 266, 154-181. https://doi.org/10.1111/j.1365-2796.2009.02121.x

[26] Melder, R.J., Whiteside, T.L., Vujanovic, N.L., Hiserodt, J.C. and Herberman, R.B. (1988) A New Approach to Generating Antitumor Effectors for Adoptive Immunotherapy Using Human Adherent Lymphokine-Activated Killer Cells. Cancer Research, 48, 3461-3469.

[27] Whiteside, T.L., Wang, Y.L., Selker, R.G. and Herberman, R.B. (1988) In Vitro 
Generation and Antitumor Activity of Adherent Lymphokine-Activated Killer Cells from the Blood of Patients with Brain Tumors. Cancer Research, 48, 6069-6075.

[28] Vujanovic, N.L., Rabinowich, H., Lee, Y.J., Jost, L., Herberman, R.B. and Whiteside, T.L. (1993) Distinct Phenotypic and Functional Characteristics of Human Natural Killer Cells Obtained by Rapid Interleukin 2-Induced Adherence to Plastic. Cellular Immunology, 151, 133-157. https://doi.org/10.1006/cimm.1993.1227

[29] Alici, E., Sutlu, T., Bjorkstrand, B., Gilljam, M., Stellan, B., Nahi, H., Quezada, H.C., Gahrton, G., Ljunggren, H.G. and Dilber, M.S. (2008) Autologous Antitumor Activity by NK Cells Expanded from Myeloma Patients Using GMP-Compliant Components. Blood, 111, 3155-3162. https://doi.org/10.1182/blood-2007-09-110312

[30] Parkhurst, M.R., Riley, J.P., Dudley, M.E. and Rosenberg, S.A. (2011) Adoptive Transfer of Autologous Natural Killer Cells Leads to High Levels of Circulating Natural Killer Cells But Does Not Mediate Tumor Regression. Clinical Cancer Research, 17, 6287-6297. https://doi.org/10.1158/1078-0432.CCR-11-1347 